\title{
Revisiting the Past: A Thematic Study of Man Booker Prize Winning Novel Wolf Hall Written by Hilary Mantel
}

\author{
Dr. Meenakshi Joshi
}

Assit.Prof. IPSA, IES Indore, India

\begin{abstract}
Man Booker Prize is the most prominent award every year provided to the finest work in fiction of literary area. The award is an opportunity and a platform to sensible literature and novelists and their work. It helps them to make their approach to global readers. The research paper is the thematic study of Wolf Hall, one of the winning novels of Booker award. The novel won the award of 2010, written by Novelist Hilary Mantel who won the award twice for her Tudor novels in series. The novel provides a window to the readers to revisit the history of the country England). Mantel Shows the England of sixteenth Century through the eyes of her Protagonist Thomas Cromwell. She has woven the national myth with the historical facts into the novel. She includes the nation defining events to explore the nation's identity. Mantel has taken the most influential and discussed period of the history which plays an important role in the history of England as a nation.
\end{abstract}

Keywords - Mythology, Prophecies, witchcraft.

Wolf Hall of Hilary Mantel is the winning novel of 2010 Booker Prize. The novel is a historical fiction based on history of Tudor era. Walter Benjamin, the writer of The Storyteller, expresses grief over the covering of information in the modern world because of its rejection of the miracles and because of its prompt verification. He privileges storytelling for keeping the story free from explanation. We live in an age in which the kind of information of which Benjamin speaks is easily accessible and globally acceptable. This is specifically true of the availability of historical information. Mantel's novel is one of the best examples where one can map the popular and public history of the early twentieth first century. The award winning fiction of Hilary Mantel is a good place to find "the most extraordinary things, marvelous things... relate with the greatest accuracy" (Benjamin) and a challenge to the prompt verification of a certain period of history.

Mantel began her career as a writer by exploring into the French Revolution and gave the manuscript A Place of Greater Safety (1992). After the success of four other novels, she returned to historical fiction in The Giant $O$ ' Brien (1998). She had not tackled history as immense both in material and in legacy until Wolf Hall and Bring up the Bodies came into the shape. These novels rest "on the shoulders of historians" but they also rest on Mantel's unique perception that comes from her being born and brought up in an Irish Catholic family. Her family background was different. Her family had been living in northern England in the years that followed World War II. She reflects her approach towards miracles in an interview:

If you were brought up in a religious setting, like Catholicism...you believe in magic, but you were also told there was something more powerful than magic and that is the invisible world created by God. And the fact is that the visible world is only the tip. I still believe that. I have a very strong sense of the world of our sense being -how can I put it-not the whole story. (Mantel "Dead are Real")

It is perhaps this spiritual belief that engages Mantel with the myths of England in her Tudor novels. The magical and supernatural stories are unavoidable and inseparable part of the novel. Though Historical fiction has been seen as "a product of romantic 
nationalism"(Anderson) yet Mantel has admitted her engagement with the nation in her historical novels. She comments that she must explore the mythological stories "since Englishness contained equal parts of both" ("Dead are Real"). The theme of theology has been woven together with national myth, magic, history, national narrative and fiction in order to reclaim lost histories and explore new national identities

Mantel writes history in Wolf Hall but she also weaves national myth into with the historical facts into the novel. As she shares in an interview "Dead are reals" that Wolf Hall may be about politics, "but it is also a song of England". In one of her essays (Mantel "No Passes") she expressed that how she felt excluded from English or British identity. She also admits about her identity that she felt a shift away from her Catholic, Northern England, and Irish ancestry:

[Mantel] planted her flag right in the center of Englishness-because nothing, she thought, could be more seminal to English identity than the reign of Henry VIII and the coming of the English Bible. Thomas Cromwell had showed the English how to know themselves: in 1538, he ordered parishes to keep records of baptisms, marriages, and burials. And now she, writing about Cromwell, would furnish another document of English selfknowledge. It would be political but also mythological since Englishness contained equal parts of both (Mantel "Dead are Real")

Mantel was not going with the mythological voice first time. She already had done this work in The Giant O'Brien "a song of Ireland". She intertwines myth and history together in the eighteenth century mystery. Mantel likes to weave mythological narratives into her historical narratives because it has the possibilities of the huge archetypes. What she has written in Wolf Hall and Bring up the Bodies is found in mythology like the female fatale, the discarded wife, and the ruler who must secure his kingdom for his descendants. Literature has already seen the treatment of the archetype of the wise man with Sir Thomas More. Rober Bolt's A Man for All Seasons and Hitchens' The Man Who Made England are presented Thomas More as Hero and demonizes Cromwell. Mantel reverses these historical models. She makes readers believe that Cromwell is the wise man while Thomas More is a saint and literary giant. There is a connection between More's evil acts and the myth. Tudor society believed that giants are evil ISSN: 2456-7620 because of their role in myth, fable and the Bible. By the late eighteenth century, giants became popular to study. As Mantel explores in her eighth novel The Giant O'Brien, Hunter, a Scottish man of Science vanquishes O'Brien, an Irish storyteller. Mantel considered it her favorite work until Wolf Hall.

In addition to mythology, witch and prophet are two things that we frequently find in her novel. In the novel, Anne Boleyn is accused of having bewitched Henry, while biographies and fictional explorations of Anne never link her to witch craft. Similarly Elizabeth Barton who appears in Wolf Hall was a prophet whose opposition to Henry's marriage to Anne resulted in Barton's death. Mantel links these two women together in the novel as women who think they can influence and manipulate the men around them only to discover their own opportunities. While the decline in many superstitious beliefs occurred, there was a decline in the belief that women were generally believed to be sexually more greedy than men. Henry's court regarded any suggestion of witchcraft attached to Anne Boleyn as an implication that she was sexually more voracious than her husband. Cromwell used this reputation of Anne Boleyn to support the charges laid against her.

Some contemporaries discussed whether the prophets had got their foreknowledge from God, from conjuration or from astrology. In the novel Eustache Chapuys, Charles's Ambassador to England and a regular visitor at Cromwell's house observes that the English are trusting and easily moved by prophecies. Mantel's Cromwell dismisses prophecies. In Wolf Hall Cromwell interrogates and convicts Elizabeth Barton for her prediction of Henry's death. English belief in magical myths like prophecies and witches has been used to motivate attacks on women who have achieved position of power especially through their intellectual abilities or their public voices. These prophecies often used as a tool for handling political power. Acquiring power and its loss is a theme in all of Mantel's work. They can be seen in the postmodern context in which Mantel lives. The characters within these myths seem to be non-aristocratic. It gives hints that only aristocrats can wield power. The women characters engaged in these myths suggest female suppression.

Though west is far away from myths and prophecies and lives in a secular age, still it is possible to say that the "demons and devils and witches and prophets have never been firmly expunged from the collective 
imagination, whether by Christianity or any other enlightening movement"(Poole 29). Mantel has presented in her novel the contemporary British society fashions itself as secular.

In the middle ages, Thomas argues in Religion and the Decline of Magic, religion, spells, curse and prophecies were the coping methods for people facing challenges of diseases and plagues without medicine and, human misfortune. Helplessness in the face of disease was an essential element in the background to the beliefs of the sixteenth century. Prophecies had the most potential for power. Usually new discovered prophecies came from monasteries and often appear during chaotic years of the sixteenth century. One example Mantel offers is the prophecy on which Cromwell relied that breach with Rome was not a new direction but returned to an old one.

Such prophecies circulated often by word of mouth but also disseminated by transmitters. This national trait facilitated the passing and enforcing of Cromwell's act in restraint of appeals because of its appropriation of an old prophecy declaring England's independence from Rome. The first chapter of Wolf Hall all speaks about how early England was formed. But this chapter opens with an imaginary myth that discovery of an island by thirty three daughters of a Greek King naming Albina. After this mythological opening, Mantel retells Anne's rise in the King's favor and hints at Cromwell's violent past. Cromwell struggles to acquire the divorce for Henry from Katherene because he needs to have a boy to secure his dynasty. This time Wolsey tells Cromwell about the Greek and Roman roots of Albion and the influence of myth or witchcraft on the power shifts of England's kings. Mantel uses Wolsey, Cromwell's mentor, as a medium of old stories in the novel Wolf Hall ,reminding us that "some people let us remember, do believe them"(Mantel 94). These old stories still circulate today in various forms. It must be the reason behind Mantel's promotion of these fundamental myths.

The belief in witches and their power to do harm was very old in the sixteenth century. Through the witches, prophets, magic and religion, Mantel creates the intertextuality between her fictional novel, the myths of the creation of England and the history of HenryVIII's break from Rome. Thomas Cromwell scoffs at the idea of using witchcraft as a basis for the charge against Anne. He was aware of the use of this treatise for persuading women. This means that Cromwell relied on the association of the devil and sexual promiscuity with witchcraft to influence the verdict of the assessors at Anne Boleyn's trial. The story of Albina and her sisters, the founder of Albion, also contains a female pact with the devil, of paganism and of female misrule. Mantel believes that "The visible world is only the tip. I still believe that. I have a very strong sense of the world of our senses being...not the whole story" ("Accumulated Anger"). She is therefore in her Tudors novels Intertwined religion with magic.

A nation's history acts as its foundation and influences its concept of national identity. It provides a collective memory to its citizens. These fables and myths travel first orally then in print form. Mantel conveys the old myths through the character Wolsey who affirm to Cromwell do believe the old myths of Brutus and Edward IV's three sons. These myths perform a major role in an early twenty first century novel about the early sixteenth century. How these myths have been passed, interpreted and organized over the centuries can be better understood through Mantel's Novel. The combined narration of myths by Wolsy in Wolf Hall and other modernist writers like T.S. Eliot, James Joyce and D. H. Lawrence invoked same myths which are used to serve a nation's political ambitions. It is well explained in one of the dissertation of Cohen. He argues that giants were just one example of a mythological trope that appears as history in medieval texts and were accepted in history likewise they appear in Bible. Giants appear in literature and folklore up until the fourteens century and this tradition got change in the earliest years of the Middle English period. It was the time when both secular and sacred myths were used as foundations for secular writing.

In Wolf Hall, Mantel relies on a version of one of these early narratives, the story of Brutus, mythological founder of Britain, and the giants of Albion. "Beneath every history, another history" (Mantel 66), this retelling is a strategy that Mantel uses to establish the prevailing medieval attitude of, inherited by Cromwell's society that a women ruler, leader or dominator of men is an abomination. By adding this narration Mantel portrays the sinfulness and sexual monstrosity of these sisters as the result of their presumption to rule. Brutus reverses this unnatural order when he arrives with his Trojan men, slaying who will be the future colonizing empire that Britain will become "no matter...it all begins with slaughter" (Mantel 66).

The Victorians rejected myth as "incompatible with science"(Segal) and made it a sub-category of religion. 
Among the theorists who sought to find other meaning and significance for myth was Ernst Cassirer. According to his view the myths in the early twentieth century are resulted from mental reception and interpretation made by earlier cultures. By taking modern approach of T. S. Eliot's modern poem The Waste Land, he found:

Myth as a psychological and social tool to cope with the guilt and anxiety that members of society feel towards their own aggression and to unite society by turning that aggression onto outsiders (Segal)

The myth of Brutus is England's fate, "its destiny as decreed from the very beginning" through colonization "it all begins in slaughter" (Mantel 66). The Albina myth is a complicated addition to this story because, rather than defeat the demons they find inhabiting their island, the sisters mate with them making love not war. It seems that the arrival of Brutus, his role in overturning the rule of the descendants of Albina, suggests a social need to establish the unnaturalness of woman as ruler. The Albina and Brutus myths, according to Cassirer continue to circulate the collective consciousness of a culture.

A state that promotes myths like these for political purposes usually makes such things to meet a political objective. The theorist argues that there always exists a binary of people characterized as demons and people characterized as divine in myths. In Nazi Germany, for example, Jews were cast in the role of the demons. In Wolf Hall the demons of England shift from beings those who follow Martin Luther to those who do not reject the Pope as the supreme head of the Church in England. Therefore Sir Thomas More is ventured but then he must die.

Cassirer, Girard and Malinowski's interpretations of myth find expressions in the use of Albina and Brutus myth in Mantel's Tudor novels. Yet, through Cromwell, Mantel also shows how new myths are made, remade and reworked. These new myths parallel the myths of the past because they narrate the origins of modern England and the birth of the nation through the machinations of King Henry VIII and his master secretary, Thomas Cromwell.

In early twentieth century, Sir James Frazer's Golden Bough: a study in magic and religion (1890) had influenced a broad range of disciplines in British society. Frazer's study examines symbols, myths and rites across culture, making connection but allowing his readers to draw their own conclusions. His influence was also seen among modernist writers such as T. S. Eliot, James Joyce and D. H. Lawrence.W.B. Yeats by re-telling the myths and folk of Ireland promoted a distinct national culture giving birth to national myth. Later on Robert Graves explored the mythological construct of The White Goddess (1948), the deity upon which the poetic tradition rests. He briefly talks about the Danaids' appearance in British history and their dismissal by John Milton while arguing for the Trans cultural importance of Albina. This is all intertextuality with the modernist implies is that Mantel through the use of myth and through the form of historical fiction is attempting to establish a new kind of national myth and a new kind of national identity through a new interpretation of a critical epoch of British history.

Shortly after winning her first Man Booker Prize for Wolf Hall, Mantel wrote an editorial for The Guardian in which she talks about the value of historical fiction. Mantel argues, "To try to engage with the present without engaging with the past is to live like a dog or cat rather than a human being ; it is to bob along on the waters of egoism solipsism and ignorance"("History in Fiction"). Her editorial is a plea for better history she said:

History offers us vicarious experience. It allows the youngest student to possess the ground equally with his elders; without knowledge of history to give him a context for present events, he is at mercy of every social misdiagnosis handed to him. (Mantel "History in Fiction")

Myth, history and literature remained interlink till the early seventeenth century for example Shakespeare's history plays. Outside of universities and schools, "the proliferation of historical pageants, the expansion of historical tourism and the popularity of historical novels (Fielding) characterized post-Victorian society. For some early twentieth century historians, this popular celebration of history was not rigorous enough; they perceived Britain to be mostly ignorant of their past. The late nineteenth and early twentieth century's saw the establishment of several societies for the preservation of historical buildings and sites. Despite the existence of these new societies, history is recognized as a professional area of study and practice. In 1980 White argued that historical data and events should be narrativized and presented in more easily form to understand. Therefore it was clear that history and literature cannot be separated. White further identified that historical facts consists of four tropes: comic, romantic, tragic and satiric. Mantel alludes to these tropes in the first epigraph of 
Wolf Hall: "There are three kinds of scenes, one called the tragic, second the comic, third the satiric"(Mantel)

Mantel weaves national myth with the historical facts into the novel. She herself says that Wolf Hall may be about politics, but it is also a song of England. The primary concern is revisiting the history of Britain behind the curtain of mythology, political upheavals, and church reformation in the Sixteenth Century. Mantel has chosen this huge archetype historical based fiction because no story can reflect England and its national identity better than the reign of Henry VIII and the coming of the English Bible. Thomas Cromwell had showed the English how to know themselves. It is political but also mythological as Englishness contained equal parts of both. Since these events are nation defining, the author chooses to set her historical fiction to define country's history and national identity. Mantel knows the value of historical fiction as she said without past one cannot be engaged with the present.

\section{REFERENCES}

[1] Anderson, Perry. "From Progress to Catastrophe: Perry Anderson on Historical Novels." London Review of Books (2011): N. pag. Web. Assessed Jan 16

[2] Allfree, Calire, An Interview with Hilary Mantel. Newzeland listener. Bauer Media Group. Web 17 Sept. 2014

[3] Benjamin,Walter. "The Storyteller". Theory of the Novel:A Historical Approach. Baltimore London. John Hopkins UP, 2000. 77-97.Print.

[4] Bordo, Susan. "Susan's Interview with Hilary Mantel”. The Creation of Anne Boleyn.www.wordpress.com Web.May 6, 2013.

[5] Greenblatt, Stephen. "How it must have been." Rev. of Wolf Hall by Hilary Mantel. The New York Review of Books. NYREW. 5 Nov 2009.: N Pag Web April 2015.

[6] Hitchens, Christopher. "The Man Who made England: Hilary Mantel's Wolf Hall" Rev. of Wolf Hall by Hilary Mantel. Arguably. Toronto:Signal/McCellend \&Stewert 2011, 146-151

[7] Mantel, Hilary. Bring up the Bodies. New Delhi Harper Collins Publisher,2012.Print.

[8] Mantel, Hilary. Wolf Hall.UK: Fourth State, 2010.Print.

[9] ---“The Dead are Real: Hilary Mantel's Imagination" Interview by Larissa Macfarquhar. The NewYork. 15 Oct. 2012. N. page.Web. 18 Oct.2015

[10] ---"Booker Winner Hilary Mantel on Dealing with History in Fiction". The Gurdian. The Gurdian News and Media Limited. 17 Oct.2009.Web Assessed 22 Dec 2015
[11] --- "I Accumulated an Anger that would Rip a Roof Off". Interview by Aida Eidmariam. Theguardian. The Guardian News and Media Limited. 12 Sept. 2009: N. pag. Web.

[12] --- "Anne Boleyn: Witch, Bitch, Temptress, Feminist." Theguardian. The Guardian News and Media Limited. N: pag. 11 May 2012. Web.

[13] Segal, Robert A. "Myth: Theoretical Approaches." Encyclopedia of Narrative Theory. London: Routlage, 2010. Web. 2014

[14] The Dead are Real: Hilary Mantel's Imagination. Interview by Larissa MacFarquhar. The New Yorker. 15 Oct. 2012. Condé Nast: N. pag. Web. 18 October 2012. 